\title{
Electroencephalograms and nerve conduction in survivors of kwashiorkor
}

\author{
By G. M. TAORI AND SHEILA M. PEREIRA \\ Department of Neurological Sciences and Nutrition Research Unit, \\ Christian Medical College and Hospital, Vellore, Tamil Nadu, India
}

(Received 1o April 1973-Accepted 3 I fuly 1973)

\begin{abstract}
1. Electroencephalographic and nerve-conduction studies were undertaken in children who had been treated in hospital for kwashiorkor 6-8 years previously; the results were compared with those for age-matched controls of similar cultural and socio-economic backgrounds.

2. The electroencephalograms were normal in all.

3. In three survivors of kwashiorkor, the amplitude of the sural nerve potential was less than that of the lower limit of the normal range.

4. The findings are discussed in the context of the present knowledge of protein-energy (protein-calorie) malnutrition.
\end{abstract}

In studies with experimental animals, undernutrition at a certain stage of development results in damage to the brain, which may remain despite refeeding at a later stage (Dobbing, 1963-4; Winick \& Noble, I966; Bass, Netsky \& Young, I970a, $b$; Cragg, 1972). Cravioto \& Robles (1965) described deficits in adaptive and motor behaviour in children with protein-energy (protein-calorie) malnutrition during rehabilitation. In more recent studies, a decrease in cellularity and in myelin lipids has been reported in the brains of children with protein-energy malnutrition (Winick \& Rosso, 1969a; Fox, Fishman, Dodge \& Prensky, 1972; Kokrady, Mukherjee, Ganguly \& Bachhawat, I973). In an earlier study from this institution, neuromuscular abnormalities in children with kwashiorkor have been described (Sachdev, Taori $\&$ Pereira, 1971).

In the few electroencephalographic (EEG) studies carried out in children with kwashiorkor, generalized as well as focal slowing in the temporal lobes was reported in the majority (Sarrony, Saint-Jean \& Clausse, I953; Engel, I956; Nelson, I959). The response to photic stimulation was also reported to be abnormal in the acute phase (Nelson, I959). With recovery, the changes in the EEG tend to revert to normal and the response to photic stimulation also improves (Engel, 1956; Nelson, 1959).

Follow-up studies on the survivors $6-8$ years after recovery from overt malnutrition have shown abnormal neurointegrative function and lower intelligence compared with controls (Stoch \& Smythe, I963; Cabak \& Najdanvic, I965; Cravioto \& Robles, I965; Cravioto, DeLicardie \& Birch, I966; Champakam, Srikantia \& Gopalan, I968; Hertzig, Birch, Richardson \& Tizard, I972). As mental function and neurointegrative performance are found to be affected in some children several years after recovery from kwashiorkor, the following studies were undertaken to determine the EEG and nerve-conduction patterns of children $6-8$ years after recovery from malnutrition. 


\section{MATERIAL AND METHODS}

\section{Subjects}

Twenty children who had previously been treated in hospital for kwashiorkor were contacted in their homes 6-8 years after recovery. 'Their parents' consent was obtained for the children's participation in follow-up studies on anthropometry, neurointegrative performance (to be published) and electroencephalographic and peripheral nerveconduction patterns. The children were studied when they were between $7 \cdot 5$ and II years of age.

\section{Controls}

Twenty children resident in two villages and attending the local schools formed the control group. They were between 8 and I I years of age and came from a socio-economic and environmental background similar to that of the children who had recovered from kwashiorkor. The heights, weights and the circumferences of the heads and chests of the children were recorded. In selecting the children who served as controls, it was established that they had been free from overt protein-energy malnutrition in early childhood.

Electroencephalograms on all the children were done on a Grass 8-channel electroencephalograph using the international $10-20$ system of scalp electrode placement. All the records were taken during the wakeful state only. Response to opening and closing of the eyes was noted. Hyperventilation for $3 \mathrm{~min}$ was used as a provocative test. Response to photic stimulation at $2-20$ flashes/s was studied.

Nerve-conduction studies were done on a MEDLEC $\mathrm{MS}_{3} \mathrm{R}$ electromyograph in an air-conditioned room, with the temperature kept constant at $28-29^{\circ}$. Motor-nerve conduction was estimated in the median and the lateral popliteal nerves by standard surface stimulation and recording techniques. Sensory conduction in the median nerve was studied by stimulating the digital nerves of the index finger by ring electrodes at the wrist. Latency, amplitude and duration of the potential were studied. Sensory conduction in the sural nerve was studied by stimulating the nerve antidromically in the leg by surface electrodes and recording the potential by surface electrodes just behind the lateral malleolus. The conduction velocity of the nerve, the amplitude and the duration of the evoked potential were recorded.

\section{RESULTS}

The children who had recovered from protein-energy malnutrition had, on their first admission to hospital, the essential features of kwashiorkor as seen in south India (Gopalan \& Ramalingaswami, 1955; Webb, Dumm \& Pereira, 1963). The ages, total serum proteins and serum albumin of the children with kwashiorkor on admission are given in Table $\mathbf{I}$. The minimum body-weights of the children after loss of oedema are also given to indicate the severity of their weight deficits.

The anthropometric measurements of the children who survived kwashiorkor are compared with those of the children who served as controls in Table 2. As some of 
Table I. Ages, serum protein and serum albumin concentrations, and minimum bodyweights after loss of oedema of the children on admission to hospital for treatment of kwashiorkor

(Mean values and standard deviations)

\begin{tabular}{|c|c|c|c|c|}
\hline $\begin{array}{c}\text { Age } \\
\text { (months) }\end{array}$ & $\begin{array}{l}\text { No. of } \\
\text { children }\end{array}$ & $\begin{array}{l}\text { Serum proteins } \\
(\mathrm{g} / \mathrm{l})\end{array}$ & $\begin{array}{l}\text { Serum albumin } \\
(\mathrm{g} / 1)\end{array}$ & $\begin{array}{l}\text { Minimum } \\
\text { body-wt (kg) }\end{array}$ \\
\hline $12-23$ & 5 & $49^{\circ} \circ \pm 5 \cdot 4$ & $I 6 \cdot 0 \pm I \cdot 2$ & $4.82 \pm 0.61$ \\
\hline $24-35$ & II & $4 \mathbf{I} \cdot \mathbf{2} \pm 8 \cdot 9$ & $15 \cdot 0 \pm 3 \cdot 9$ & $7.65 \pm 0.87$ \\
\hline $3^{6}$ & 4 & $39^{-8} \pm 3^{.9}$ & $13.4 \pm 3^{6}$ & $9 \cdot 20 \pm r \cdot 4^{8}$ \\
\hline All ages & 20 & $42 \cdot 9 \pm 8 \cdot 3$ & $14 \cdot 9 \pm 3.4$ & $7 \cdot 25 \pm 1.80$ \\
\hline
\end{tabular}

Table 2. Height, weight and circumference of head of the children who survived kwashiorkor in early childhood and of the controls

(Mean values and standard deviations)

\begin{tabular}{|c|c|c|c|c|c|c|c|c|}
\hline \multirow[b]{2}{*}{$\begin{array}{c}\text { Age } \\
\text { (years? }\end{array}$} & \multicolumn{4}{|c|}{ Survivors of kwashiorkor } & \multicolumn{4}{|c|}{ Controls } \\
\hline & $\begin{array}{l}\text { No. of } \\
\text { children }\end{array}$ & $\begin{array}{c}\mathrm{Ht} \\
(\mathrm{mm})\end{array}$ & $\begin{array}{l}\mathrm{Wt} \\
(\mathrm{kg})\end{array}$ & $\begin{array}{l}\text { Head cir- } \\
\text { cumference } \\
(\mathrm{mm})\end{array}$ & $\begin{array}{l}\text { No. of } \\
\text { children }\end{array}$ & $\underset{(\mathrm{mm})}{\mathrm{Ht}}$ & $\begin{array}{l}\mathrm{Wt} \\
(\mathrm{kg})\end{array}$ & $\begin{array}{l}\text { Head cir- } \\
\text { cumference } \\
(\mathrm{mm})\end{array}$ \\
\hline $7:$ & 3 & $\begin{array}{r}1069 \\
\pm 24\end{array}$ & $\begin{array}{r}16.50 \\
\pm 0.58\end{array}$ & $494 \pm 18$ & - & - & - & - \\
\hline 8 & 9 & $\begin{array}{r}\operatorname{Irr2} \\
\pm 57\end{array}$ & $\begin{array}{r}16 \cdot 52 \\
\pm 2 \cdot 32\end{array}$ & $488 \pm I 6$ & 9 & $\begin{array}{l}\text { I } 175 \\
\pm 37\end{array}$ & $\begin{array}{r}19 \cdot 18 \\
\pm 1 \cdot 12\end{array}$ & $505 \pm 26$ \\
\hline 9 & 7 & $\begin{array}{r}1176 \\
\pm 72\end{array}$ & $\begin{array}{r}19.53 \\
\pm 3.91\end{array}$ & $495 \pm 22$ & ro & $\begin{array}{r}1238 \\
\pm 47\end{array}$ & $\begin{array}{r}20 \cdot 99 \\
+1 \cdot 52\end{array}$ & $502 \pm 10$ \\
\hline 10 & $\mathbf{I}$ & I 135 & 19.85 & 500 & I & $\times 250$ & $20 \cdot 90$ & 500 \\
\hline All ages & 20 & $\begin{array}{r}1129 \\
\pm 68\end{array}$ & $\begin{array}{r}17 \cdot 74 \\
\pm 3 \cdot 17\end{array}$ & $492 \pm 19$ & 20 & $\begin{array}{r}1210 \\
\pm 53\end{array}$ & $\begin{array}{r}20 \cdot 17 \\
\pm \mathrm{I} \cdot 59\end{array}$ & $503 \pm 19$ \\
\hline
\end{tabular}

the girls showed early development of secondary sexual characteristics, the circumferences of the chest were omitted.

The children who had kwashiorkor were shorter and lighter than their controls. The differences in heights and weights between the two groups were statistically significant $(P<0.001$ and $P<0.01$ respectively). The children who survived malnutrition had smaller head circumferences than the children who served as controls, though the difference between the groups was not of statistical significance. The heights and weights of the children who had recovered from malnutrition and of the control subjects are shown in Fig. I with, for comparison, the height and weight curves for urban and rural Indian children (Indian Council of Medical Research, 1959).

Five of the children who had survived kwashiorkor had not gone to school and two others had discontinued their studies after a year or two for reasons unconnected with their learning ability. Seven children were in the first three classes without previous failures (one child was in the first class, three were in the second and three in the third). However, six other children had failed in the first and second classes and had to remain in them. In the control group, one child was in the second class, five 


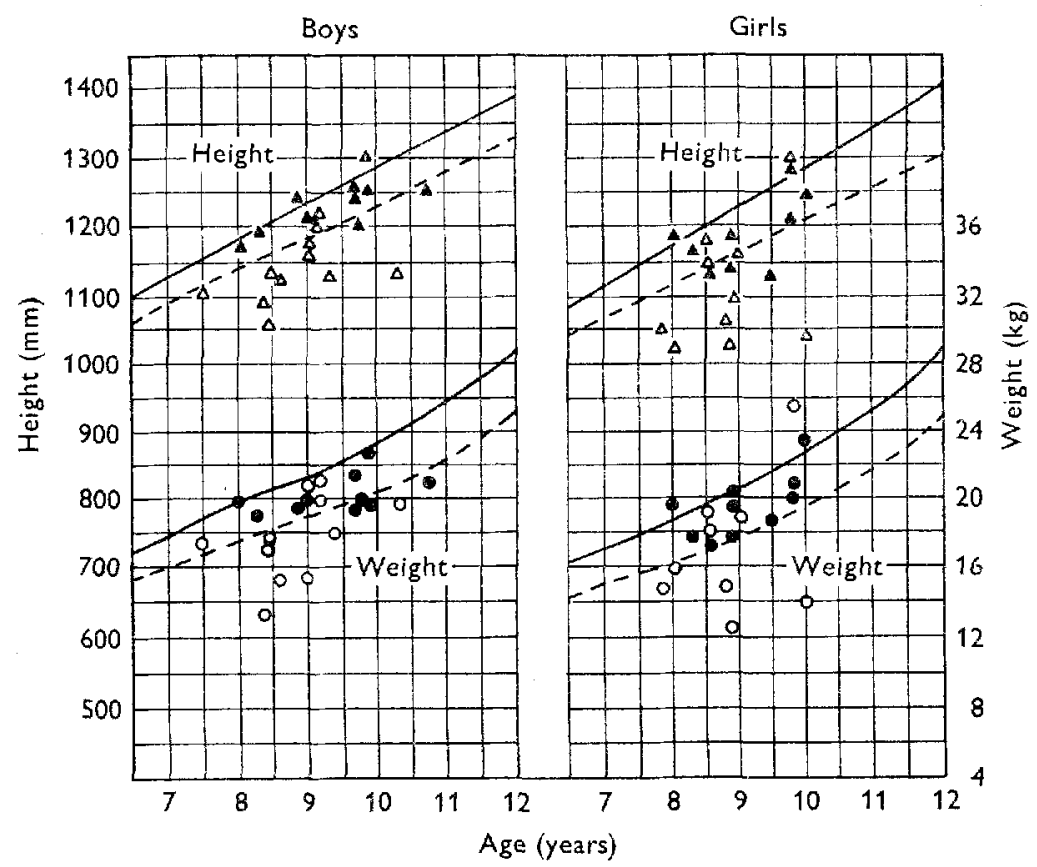

Fig. I. Heights $(\triangle)$ and weights $(O)$ of the children who had previously suffered from proteincalorie malnutrition comparcd with the heights $(\boldsymbol{\Delta})$ and weights $(6)$ of the children who served as controls. The height and weight curves of Indian urban (_-) and rural (_- - ) children are also shown (Indian Council of Medical Research, r959).

each were in the third and fourth classes and nine were in the fifth class: their scholastic achievements were commensurate with their ages.

Electroencephalographic studies were undertaken in the children who had recovered from kwashiorkor within a few months of the first contact. At the time the electroencephalograms were obtained and the nerve-conduction studies were carried out, all the subjects were between 8 and I I years of age.

The frequency of alpha activity varied between 8 and $10 \mathrm{~Hz}$ in both control and patient groups and the reactivity to opening of the eyes was normal in all. Amplitude of the alpha activity ranged between 30 and $\mathrm{I} 50 \mu \mathrm{V}$ in both the groups without any difference. Theta activity of $4-6 \mathrm{~Hz}$, mostly in frontal and temporal regions, was again noted equally in both the groups. Fast rhythms of $15^{-2} 5 \mathrm{~Hz}$ were also equally developed. Hyperventilation produced slowing in both the groups and was considered within normal limits. Response to photic stimulation as judged by 'driving response' in the occipital regions was again well developed in both the groups. In short, electroencephalograms in the wakeful state and the response to hyperventilation and photic stimulation were within normal limits.

The results of the nerve-conduction tests are summarized in Table 3 . Differences between the mean values for the control and patient groups were not statistically significant. However, in three survivors of malnutrition, the amplitude of the sural nerve potential was below the lower limit of the normal range. 
Table 3. Distal latency $(D L)$, conduction velocity $(C V)$ and amplitude $(A)$ of potential in the peripheral nerves of children who survived kwashiorkor and of the control group

\begin{tabular}{|c|c|c|c|c|c|c|c|c|}
\hline \multirow[b]{2}{*}{ Group } & \multicolumn{2}{|c|}{ Median motor } & \multicolumn{2}{|c|}{$\begin{array}{l}\text { Lateral popliteal } \\
\text { motor }\end{array}$} & \multicolumn{2}{|c|}{ Sural sensory } & \multicolumn{2}{|c|}{ Median sensory } \\
\hline & $\begin{array}{c}\mathrm{DL} \\
(\mathrm{ms})\end{array}$ & $\begin{array}{c}\mathrm{CV} \\
(\mathrm{m} / \mathrm{s})\end{array}$ & $\begin{array}{l}\mathrm{DL} \\
\text { (ms) }\end{array}$ & $\begin{array}{c}\mathrm{CV} \\
(\mathrm{m} / \mathrm{s})\end{array}$ & $\begin{array}{c}\mathrm{A} \\
(\mu \mathrm{V})\end{array}$ & $\begin{array}{c}\mathrm{CV} \\
(\mathrm{m} / \mathrm{s})\end{array}$ & $\begin{array}{c}\mathrm{A} \\
(\mu \mathrm{V})\end{array}$ & $\begin{array}{l}\text { Latency* } \\
\text { (ms) }\end{array}$ \\
\hline \multicolumn{9}{|l|}{ Survivors: } \\
\hline Mean value & $2 \cdot 43$ & 54.56 & $2 \cdot 86$ & $5 I \cdot 8 I$ & $17 \cdot 72$ & $48 \cdot 94$ & $34 \cdot 33$ & $I \cdot 74$ \\
\hline SD & 0.27 & $5 \cdot 29$ & $0.4 I$ & 3.19 & $9-17$ & $5 \cdot 26$ & I2. 8 & 0.17 \\
\hline Range & $2 \cdot 0-2 \cdot 9$ & $41 \cdot 5-60$ & $2 \cdot 3-3 \cdot 9$ & $46 \cdot 5-57$ & $6-40$ & $42 \cdot 5-54$ & $10-60$ & $I \cdot 4-2 \cdot 0$ \\
\hline \multicolumn{9}{|l|}{ Controls: } \\
\hline Mean value & $2 \cdot 55$ & 55.92 & $3 \cdot 24$ & $50 \cdot 29$ & $21 \cdot 95$ & $47 \cdot 82$ & $36 \cdot 18$ & $x \cdot 75$ \\
\hline SD & 0.33 & $4 \cdot 78$ & 0.69 & 4.07 & $10 \cdot 58$ & $5 \cdot 16$ & 10.14 & 0.27 \\
\hline Range & $I \cdot 9-3 \cdot I$ & $49-68$ & $2 \cdot 5-5 \cdot 1$ & $41 \cdot 5-57$ & $10-60$ & $39^{-8-60}$ & $20-60$ & $I \cdot 4-2 \cdot 2$ \\
\hline
\end{tabular}

\section{DISCUSSION}

The damage sustained by the developing nervous system during a period of undernutrition has been established by several studies (Sugita, 1918; Horn, 1955; Eayrs \& Horn, I955; Eayrs \& Goodhead, 1957; Dobbing, 1963-4; Platt \& Stewart, I969; Bass et al. 1970 a, $b$; Cragg, 1972). In tests of intelligence, the performance is poorer in children who survived malnutrition in their earlier years, in comparison with siblings or normal children (Stoch \& Smythe, 1963; Cabak \& Najdanvic, 1965; Champakam et al. 1968; Hertzig et al. 1972). It has also been noted that neurointegration of the special senses is delayed in children who have suffered from proteinenergy malnutrition in early childhood (Cravioto 8 Robles, 1965; Cravioto et al. 1966). These children may be left with a permanent impairment of intelligence and become less effective citizens.

In the acute phase of the illness, most children exhibit behavioural changes, and their electroencephalograms have been shown to be abnormal (Sarrony et al. 1953; Engel, 1956; Nelson, 1959; Valenzuala, Hernandez-Peniche \& Macias, 1959). In two patients whose mentation was normal, Engel ( 1956 ) reported normal electroencephalograms. During recovery, over a period of a few weeks to a few months, the electroencephalograms of the children became normal (Engel, 1956; Nelson, I959; Valenzuala et al. 1959). Myslivecek \& Hassmannova (1962), and more recently Mourek, Himwich, Myslivecek \& Callison ( 1967 ) have reported changes in the evoked potential in chronically starved animals despite the resumption of normal feeding. However, it should be noted that in these animals the basic rhythms were slower than in control animals. Nelson (1959) reported a depressed response to photic stimulation in children with kwashiorkor in the acute stage, with distinct improvement in the evoked response during recovery.

In the present study, children showed normal resting encephalograms and normal responses to hyperventilation and photic stimulation 6-8 years after recovery from kwashiorkor. However, the latter in the routine electroencephalogram is not a very satisfactory method of studying the evoked response. 
Histological and biochemical changes were recorded in the neurons and myelin of children with kwashiorkor at autopsy (Winick \& Rosso, 1969a, b; Fox et al. 1972; Kokrady et al. 1973). In experimental animals, diminished dendritic arborization and axonal terminals have been demonstrated (Eayrs \& Horn, I955; Horn, 1955; Eayrs \& Goodhead, I957; Cragg, 1972). On refeeding the experimentally malnourished animals, Horn (I955) did not find any statistically significant change in the dendritic arborizations. It is possible that a study by more sophisticated techniques of evoked responses in children who have recovered from malnutrition might reveal abnormality.

The involvement of the peripheral nervous system and muscle has been demonstrated in the acute stage of the illness by Sachdev et al. (197r). In the present study, in three children who had previously suffered from kwashiorkor, the amplitude of the evoked response from the sural nerve was low, despite normal conduction velocity, a finding that may indicate a smaller number of nerve fibres in the sural nerves of the subjects, than in those of the other children. The lower amplitude of the evoked response in three children did not correlate with other measurements such as the onset of illness, height, weight and performance of neurointegrative psychometric tests. It is difficult to ascribe the change in the evoked response solely to the acute proteinenergy deprivation that had occurred several years ago, for a continued deficiency of nutrients might have played a part. However, it is very likely that the children serving as controls had also been exposed to similar nutritional deficiencies, which are widely prevalent in this geographical area (Rao \& Rao, 1958; Sundararaj, Almas Begum, Jesudian \& Pereira, 1969), and it is probable that the findings in the survivors are related to the acute deprivation they suffered in the past.

This work was supported by Agreement no. oI-002-I PL 480 Funds, from the National Institutes of Health, United States Public Health Service. The authors thank Mr Sampathkumar Mathews for statistical analyses of the results.

\section{REFERENCES}

Bass, N. H., Netsky, M. G. \& Young, E. (1970a). Archs Neurol., Chicago 23, 289. Bass, N. H., Netsky, M. G. \& Young, E. (1970b). Archs Neurol., Chicago 23, 303. Cabak, V. \& Najdanvic, R. (1965). Archs Dis. Childh. 40, 532.

Champakam, S., Srikantia, S. G. \& Gopalan, C. (1968). Am. F. clin. Nutr. 21, 844.

Cragg, B. G. (1972). Brain 95, 143.

Cravioto, J., DeLicardie, E. R. \& Birch, H. G. (I966). Pediatrics, Springfield 38, $3^{\text {I } 9 .}$

Cravioto, J. \& Robles, B. (1965). Am. F. Orthopsychiat. 35, 449.

Dobbing, J. (1963-4). Proc. R. Soc. B 159, 503.

Eayrs, J. T. \& Goodhead, B. ( 957$).$ F. Anat. 93, $3^{8}$.

Eayrs, J. T. \& Horn, G. (1955). Anat. Rec. 121, 53 .

Engel, R. (1956). Electroenceph. clin. Neurophysiol. 8, 489 .

Fox, J. H., Fishman, M. A., Dodge, P. R. \& Prensky, A. L. (1972). Neurology, Minneap. 22, 1213.

Gopalan, C. \& Ramalingaswami, V. (1955). Indian F. med. Res. 43, 75 I.

Hertzig, M. E., Birch, H. G., Richardson, S. A. \& Tizard, J. (I972). Pediatrics, Springfield 49, 8 I 4.

Horn, G. (1955). Anat. Rec. I21, 63.

Indian Council of Medical Research (1959). Annual Report of the Nutrition Research Laboratories, Hyderabad, pp. 43-48.

Kokrady, S., Mukherjee, K. L., Ganguly, C. \& Bachhawat, B. K. (I973). Indian 7. Biochem. Biophys. (In the Press.)

Mourek, J., Himwich, W. A., Myslivecek, J. \& Callison, D. A. (Ig67). Brain Res. 6, 24 I. 
Myslivecek, J. \& Hassmannova, J. (I962). Quoted by Mourek, Himwich, Myslivecek \& Callison (I967). Nelson, G. K. (1959). Electroenceph. clin. Neurophysiol. II, 73.

Platt, B. S. \& Stewart, R. J. C. (I969). Devl. med. Child Neurol. II, 174.

Rao, B. R. H.\& Rao, P. S. S. (1958). Indianf. med. Sci. rz, 7 r8.

Sachdev, K. K., Taori, G. MI. \& Pereira, S. M. (197 I). Neurology, Minneap. 21, 801.

Sarrony, C. H., Saint-Jean, M. \& Clausse, J. (I953). Quoted by Nelson (1959).

Stach, M. B. \& Smythe, P. M. (1963). Archs Dis. Childh. 38, 546.

Sugita, N. (1918). F. comp. Neurol. 29, 6r.

Sundararaj, R., Almas Begum, Jesudian, G. \& Pereira, S. M. (x969). Indian f. med. Res. 57, 375.

Valenzuala, R. H., Hernandez-Peniche, J. \& Macias, R. (I959). Quoted by Cravioto, DeLicardie \& Birch (1966).

Webb, J. K. G., Dumm, M. E. \& Pereira, S. M. (1963). Report on Seminar on Protein Malnutrition in Children, pp. 44-6o. New Delhi: World Health Organization.

Winick, M. \& Noble, A. (1966). F. Nutr. 89, 300.

Winick, M. \& Rosso, P. (1969a).尹. Pediat. 74, 774.

Winick, M. \& Rosso, P. (1960b). Pediat. Res. 3, 181 . 